\title{
Factor Analysis of Occurring Transactional Costs in an Educational Establishment
}

Vorontsova L.V.a

Safiullin N.Z. ${ }^{b}$

Kramin T.Vc

Timiryasova A.V. ${ }^{\text {d }}$

\author{
acd Institute of Economics, Management and Law, Kazan, Russian Federation, 420111 \\ ${ }^{b}$ Kazan Federal University, Institute of Management, Economics and Finance, Kazan, 420008, Russia
}

\section{Doi:10.5901/mjss.2015.v6n1s3p193}

\begin{abstract}
The article views informational environment and specific features of internal institutional environment of an educational establishment in order to reveal the prerequisites and factors of transactional costs occurring during its functioning. The main directions of reducing the transactional costs of an educational establishment are defined.
\end{abstract}

Keywords: transactional costs, institutional environment, educational establishment, informational system, organizational-functional structure

The majority of researchers studying the issues of transactional costs management agree that these costs are of informational character (Williamson \& Winter, 1993; Т. Крамин, 2006; Олейник, 2005). Besides, transactional costs are formed in an institutional environment, in the system of public rules and agreements, both formal and informal. Consequently, the subjective factors, determined by the behavior of individuals and groups, are of key importance in forming transactional costs (RW McMeekin, 2001; Robert McMeekin, 2003; Rowan, Meyer, \& Rowan, 2006; Rowan \& Miskel, 1999, pp. 378-379).

Taking into account these provisions, the proposed article studies the informative environment and the specifics of the internal institutional environment of an educational establishment in order to reveal the prerequisites and factors of transactional costs occurring during its functioning.

The topicality of the presented work is due to the fact that under informational economy and knowledge economy, towards which the world economy system is rapidly moving, the subjective factors in the educational establishment management system become more significant every year. The subjectivity of management is revealed in all management systems, from the process organization up to the issues of control and decision-making.

The analysis of university management system revealed the main elements influencing the informational provision and depending on the automatization of the educational process management.

The analysis was carried out on the data of the following educational establishments: Kazan State Institute for Finance and Economics (KFU); Kazan State University (KFU); Kazan Technological University; Samara State University for Economics; Institute of Economics, Management and Law (Kazan).

The subjective factors influencing the automatization of the management system, with this process referring to the control function of management, and determining the composition and level of transactional costs (Воронцова, Крамин, \& Крамин, 2011; Крамин, 2007a), are most vividly seen in the form of organizational-technical elements:

1. Strategic goal and tasks of an educational establishment.

2. Interests of the parties - the lecturers, administration, community, employers, and students.

3. Organizational aspect. The existing organizational structure composed of the functional structure and official regulations. The styles of personnel management.

4. The level of control of goals achievement and tasks solving. The norm of control.

5. Other factors influencing the educational process and main informational streams management. 


\section{Organizational Aspect. The Existing Organizational Structure Composed of the Functional Structure and official Regulations. The Styles of Personnel Management}

Building an organizational structure of a university consists in determining the university's structural subdivisions, taking into account their interaction when solving the tasks of innovative activity stimulation and strategic functions for their implementation ${ }^{1}$.

The management of an educational establishment is carried out by an attested head, director, rector or other official of the educational establishment.

Article 12 of the Law "On higher and post-graduate education" states that "management of a higher educational establishment is carried out in compliance with the Russian legislation, the standard decree of the higher educational establishment and the charter of the higher educational establishment by the principles of combining the individual and collective authority... The general leadership of a state or municipal higher educational establishment is carried out by an elected representative body - the Academic Council, while the direct management of a higher educational establishment is executed by the rector ...».

The experience of countries with the developed market economy, as well as developing markets, shows that under post-industrial economy the speed and quality of informational streams are key factors of any organization's competitiveness. This is still more important for high-technology, innovative sector, including education. The traditional linear-functional structure has a number of drawbacks and limitations, first of all, in the speed and completeness of informational streams (see Table 1). This is due to the subordination to one person, the rector, of many functional workers, which makes the necessary control impossible. This provision is true for operational managerial tasks.

Table 1. Problems connected with non-optimal organizational structures and managerial systems of a university

\begin{tabular}{|c|c|c|c|}
\hline № & Managerial problems & $\begin{array}{l}\text { Opportunities connected with the } \\
\text { changes in organizational-legal forms }\end{array}$ & $\begin{array}{l}\text { Risks connected with the changes in organizational- } \\
\text { legal forms }\end{array}$ \\
\hline 1 & $\begin{array}{l}\text { Weak manageability of } \\
\text { university structures }\end{array}$ & $\begin{array}{l}\text { Increasing manageability by } \\
\text { strengthening the federal and regional } \\
\text { levels of university management }\end{array}$ & $\begin{array}{l}\text { 1. Decreasing manageability at the initial stage of } \\
\text { introducing the new managerial system. 2. Gaps } \\
\text { between the levels of university management, isolation } \\
\text { and opposition of the university top-management to its } \\
\text { other levels }\end{array}$ \\
\hline 2 & $\begin{array}{l}\text { Lack of flexibility of the } \\
\text { university organizational } \\
\text { structure }\end{array}$ & $\begin{array}{l}\text { No new opportunities increasing the } \\
\text { university rights for organizational } \\
\text { development, compared to the existing } \\
\text { legislation }\end{array}$ & \begin{tabular}{|l} 
Deformation of organizational structures due to \\
orientation towards operational issues
\end{tabular} \\
\hline 3 & $\begin{array}{l}\text { Self-sufficient, lacking } \\
\text { feedback, system of } \\
\text { goal setting and } \\
\text { performance } \\
\text { assessment of } \\
\text { universities }\end{array}$ & $\begin{array}{l}\text { Strengthening the connection and impact } \\
\text { of the regional educational system and } \\
\text { labor market }\end{array}$ & $\begin{array}{l}\text { 1. Increasing centralization in making key managerial } \\
\text { decisions. 2. Breaking the forming market tools of goal } \\
\text { setting and performance assessment of universities }\end{array}$ \\
\hline 4 & $\begin{array}{l}\text { Orientation of university } \\
\text { management to solving } \\
\text { mainly the internal } \\
\text { problems of the } \\
\text { university }\end{array}$ & $\begin{array}{l}\text { Shifting the university activity focus due } \\
\text { to changing the mechanisms of } \\
\text { university financing }\end{array}$ & $\begin{array}{l}\text { Unpreparedness of the university management to the } \\
\text { new conditions. Conflict between the "budget" and } \\
\text { "market" thinking }\end{array}$ \\
\hline 5 & $\begin{array}{l}\text { Inefficient managing of } \\
\text { state property }\end{array}$ & Strengthening control and transparency & $\begin{array}{l}\text { Decreasing the level of responsibility of administrative } \\
\text { management }\end{array}$ \\
\hline
\end{tabular}

When considering the organizational structure as the basic element of informational system, including the informational network and users' role s distribution, it is necessary to define the conceptual model of this structure.

Elaborating the structure model should imply not only elements of routine educational activity, but also the issues of the dynamic development of the educational establishment, first of all, in the field of innovative and scientific development, which, in turn, determines the informational environment of the university - the unity of informational infrastructure, corporate data and informational system aimed at automatization of the university tasks.

1 See also (Tolofari, 2005). 
Thus, the organizational-managerial structure of a university is a complex of managerial subdivisions of the university, relations and links between them occurring during implementations of the procedures of educational process management and the projects of the university innovative activity stimulation. The relations and links between the university subdivisions are expressed in the procedures of their activities' organization and mutual coordination.

The subjective factors determining the optimality of the organizational-managerial structure are the following: features of educational technologies; features of the students' contingent (preparation level of the matriculated; number of students; conditions of teaching, etc.); educational process organization (shifts; size of groups and streams, etc.); conjuncture of educational services market; nomenclature of majors, etc.

Assessing the existing organizational-managerial and functional structure of a university and adapting it to the market capabilities of activity stimulation, one should consider the following principles:

1) Functional division and specialization of managerial work. Subdivisions of a university should be divided into the main and auxiliary ones, and be formed according to the main stages of the managerial cycle;

2) Consideration of the complexity and specific features of works in accordance with the executed managerial functions. That is why the norms of the university subdivisions' functioning should be different for various types of managerial functions;

3) Proportion and contingency between managerial links, necessary for overcoming the "bottlenecks" in management;

4) Using the typical and unified elements for educational process management at a university;

5) Providing the necessary level of regulation of the university organizational-managerial structure. The objects of regulation are such characteristics as the composition and number of links, forms of relationships and links, etc.

The main goals of changing the organizational structure are improving the quality of educational services, increasing the flexibility of the educational process, reducing costs and, consequently, dynamic improving of the educational process, and the balanced development of all university subdivisions.

One of the constituent parts of reorganizing the university organizational-managerial structure for its rationalization, is elaboration of coordination mechanisms, promoting the adaptation to the new external conditions and increasing the efficiency of the university innovative activity.

Under uncertain demand for educational services, the university should change the rigid administrative management for the more flexible one (Brown, 1992), with elements of decentralization in the university subdivisions' management (a good example of such decentralization is Kazan Technological University).

Under dynamic changes of technology, the significance of the quality of educational process significantly grows. The more actively a university introduces new educational technologies and implements the projects of its innovative activity stimulation, the more often it turns to the horizontal pattern if cooperation, which characterizes the level of flexibility. One can suggest that the increase of the educational process quality directly depends on the degree to which flexibility allows to combine the external complexity and uncertainty with the limits of internal complexity of the university organizational-managerial structure.

Flexibility allows the university to rapidly change its activity in the market, directions of specialists training, and educational technologies, without disturbing the neutral subdivisions of the university.

A university with a high level of educational process organization is characterized by: decentralization, matrix organizational structure; non-authoritative management, high reliability of groups of lecturers and staff; support of promising suggestion for improving the educational process.

The specialists' training in new majors can be organized by the matrix principle, when at the first stages of preparation the educational centers are formed on the basis of inter-departmental cooperation. The final goal of the organizational structures' transformation is forming the multifunctional teams and minimizing the number of hierarchical levels. After setting up of a quality educational process, the centers are substituted for a classical system of specialists training. This form allows to attract the most qualified lecturers and us their experience, thus avoiding some typical drawbacks of forming the "new" subdivisions within the rational organizational-managerial structure of a university. This form can be used if the invited lecturers are materially motivated, especially under education commercialization.

Nowadays under transition to new curricula and teaching programs, competitive in the vague market, one should actively stimulate innovative work at university, for which it is necessary to form a rational organizational-managerial structure of the university.

The period of making new curricula and teaching programs, preparing teaching-methodological literature and software should shorten. For that, most optimal are the rational organizational-managerial structures of the university with horizontal coordination and informal interaction patterns based on mutual-decision making. 
Thus, we can formulate the following primary tasks, occurring during the building of a rational organizationalmanagerial structure of a university for its innovative activity stimulation:

1) transformation of organizational structures in the described directions;

2) sufficient transformation of informational-communicative system for its innovative activity stimulation;

3) reorganization of the work with subdivisions; changing the professional instructions; retraining of the personnel;

4) formation of new schemes and principles of work organization in the new rational organizational-managerial structure of a university and analysis of economic effect after the transformations (calculation of the transactional costs reduction);

5) as the new managerial technology leads to the increase of informational streams, the costs of management computerization should be calculated;

6) making organizational decisions of creating new positions with advanced professional requirements, considering difficulties when searching for new employees.

Due to the above specific features, creation of a rational organizational-managerial structure of a university for its innovative activity stimulation should be carried out as an integral process with a possibility to revise the structure during its projecting.

To create a rational organizational-managerial structure of a university and ensure its functioning, qualified personnel is required, as well as experts in various directions of activity. Due to the multi-profile character of universities, there are specialists in all spheres of strategic development, who can be involved into the implementation of the programs for its innovative activity stimulation, either full-time or part-time. The content and structure of the sectors' functions can be broadened and revised during the functioning of the strategic development department of a university.

Together with creating and developing the specialized structures and departments at university, for its innovative activity stimulation, special attention should be paid to the development of direct contacts with the educational services market and the main engine of a university - the lecturers. While the subdivisions are engaged in technical issues and comparative analysis of various activities in the sphere innovative activity stimulation, the link of a lecturer with the educational services market should become a tool for directing their disciplines towards satisfying the educational needs of particular customers. Activation of innovative work under uncertainty increases transactional costs and requires new methods of their reduction.

\section{The Level of Control of Goals Achievement and Tasks Solving. The Norm of Control}

The issues of the controlling function implementation in higher educational establishments are not sufficiently represented in the professional literature. At the same time, the controlling measures are a traditional and one of the most significant items of transactional costs² (Speklé, 2001).

The "control" category at universities ${ }^{3}$ is usually applied to the monitoring of students' knowledge and education quality control (Попов \& Симонова, 2005). However, control is rarely viewed by object.

In the controlling function over the university innovative activity, several spheres of research can be distinguished:

1. the share of non-budget (market) component in the university educational activity and competitiveness of the educational services;

2. the quality and assortment of the offered services;

3. the demographic situation;

4. the market research and research in the sphere of university innovative activity stimulation;

5. pre-university and post-graduate services for educational services' consumers as structural elements of a university;

6. employment of graduates, promotion of educational services and goods, advertisement;

7. results of commercial and other profitable activity of the university.

Thus, the research revealed the main elements influencing the informational provision and depending upon the directions of the educational process management automatization, the rules and features of particular educational establishments' functioning. As a result, the factors and spheres of occurring transactional costs are found.

The main attention was paid to the organizational-functional structures of educational establishments and their informational systems. The main directions of their transformation for the transactional costs reduction are revealed. The

\footnotetext{
2 See also issues of analysis made on performance indicators (Van Thiel \& Leeuw, 2002).
}

${ }^{3}$ See for instance (Lewis \& Smith, 1994; Seymour, 1992; Trow \& Clark, 1994). 
logical continuation of the research is the evaluation of transactional costs by the above groups of factors, as well as using the project management technique for creating a program of measures for their reduction.

\section{References}

Brown, B. W. (1992). Why governments run schools. Economics of Education Review, 11(4), 287-300.

Kramin, M. V., Safiullin, L. N., Kramin, T. V., \& Timiryasova, A. V. (2014). Drivers of economic growth and investment attractiveness of Russian regions. Life Science Journal, 11(6s).

Kramin, T. V., Ismagilova, G. N., \& Kramin, M. V. (2014). Assessment of Effect of Large Investment Projects on Development of Investment Potential of Regions of Russia as Exemplified by Universiade 2013 in Kazan1. Mediterranean Journal of Social Sciences, 5(18), 255.

Lane, J. E., \& Kivisto, J. A. (2008). Interests, information, and incentives in higher education: Principal-agent theory and its potential applications to the study of higher education governance. Higher Education, 141-179.

Lewis, R. G., \& Smith, D. H. (1994). Total Quality in Higher Education. Total Quality Series: ERIC.

McMeekin, R. (2001). A Theoretical and Empirical Study of Institutions Inside School Organizations/Robert W. McMeekin/Institutions and Governance:(5th Annual Conference of the International Society for New Institutional Economics. Papers), Berkeley, California, USA, September 13-15, 2001/The International Society for New Institutional Economics: Berkeley.

McMeekin, R. (2003). Networks of schools. education policy analysis archives, 11(16), 116-131.

Rapp, G. C. (2000). Agency and choice in education: Does school choice enhance the work effort of teachers? Education Economics, $8(1), 37-63$.

Nagimova, A.M., Safiullina, F.R. (2014). Combination of university training with employment among Kazan' students. Sotsiologicheskie Issledovaniya, (4), pp. 121-124.

Tsertseil, J.S. The way of clusters uprising and development in the region (By the example of the petrochemical cluster in the republic of Tatarstan). Mediterranean Journal of Social Sciences, Volume 5, Issue 18 SPEC. ISSUE, 2014, Pages 125-128

Rowan, B., Meyer, H., \& Rowan, B. (2006). The new institutionalism and the study of educational organizations: Changing ideas for changing times. The new institutionalism in education, 15-32.

Safina, D., Podgornaya, A. (2014). Mobbing as an organizational phenomenon impeding implementation of changes. Mediterranean Journal of Social Sciences, 5 (18 SPEC. ISSUE), pp. 187-192.

Rowan, B., \& Miskel, C. G. (1999). Institutional theory and the study of educational organizations. Handbook of research on educational administration, 2, 359-383.

Speklé, R. F. (2001). Explaining management control structure variety: a transaction cost economics perspective. Accounting, Organizations and Society, 26(4), 419-441.

Timiryasova, A. V., \& Kramin, T. V. (2014). Defining priorities of management of investment attractiveness of the region and their consideration in the framework of implementing large sports events. Archiv EuroECO, 2(1), 47.

Tolofari, S. (2005). New public management and education. Policy Futures in Education, 3(1), 75-89.

Trow, M., \& Clark, P. (1994). Managerialism and the Academic Profession: Quality and Control. Higher Education Report No. 2: ERIC.

Van Thiel, S., \& Leeuw, F. L. (2002). The performance paradox in the public sector. Public Performance \& Management Review, 267281.

Williamson, O. E., \& Winter, S. G. (1993). The nature of the firm: origins, evolution, and development: Oxford University Press. 